\title{
Formulasi Roti Tawar dengan Subtitusi Tepung Ubi Jalar dan Tepung Tempe Kedele \\ (Kajian terhadap Kualitas Kimiawi Roti Tawar)
}

\author{
Idiek Donowarti ${ }^{1}$ \\ ${ }^{1)}$ Fakultas Pertanian Universitas Wisnuwardhana Malang
}

\begin{abstract}
ABSTRAK
Penelitian ini bertujuan untuk mengetahui pengaruh proporsi bahan (tepung terigu, tepung ubi jalar dan tempe terhadap kualitas kimia roti tawar yang dihasilkan, sehingga akan mengurangi ketergantungan terhadap tepung gandum dan mengurangi masalah KKP (kurang kalori protein)

Penelitian dilakukan dengan metode Percobaan experimental. Penelitian terdiri dari dua tahap Tahap pertama untuk mendapatkan komposit tepung terigu dan tepung ubi jalar yang paling baik. Tahap kedua ditujukan untuk mendapatkan formulasi tepung terigu, tepung ubi jalar dan, tepung tempe yang paling baik melalui pengamatan parameter kadar air, kadar protein, kadar lemak, kandungan serat kasar dan kadar abu.

Hasil penelitian menunjukan bahwa tepung komposit yang terbaik adalah tepung terigu $80 \%$, tepung ubi $20 \%$ yang memberikan kadar lemak $1,07 \%$, kadar protein 10,88\%, kadar air 10,995\%, kandungan serat kasar 0,03\% dan kadar abu $0,92 \%$.. Penambahan tepung tempe secara proporsional yang terbaik adalah $5 \%$, yang memberikan volume kadar lemak 5,056\%, kadar protein 7,618\%, kadar air $30,976 \%$, kandungan serat kasar 1,162\% dan kadar abu 2,544\%,
\end{abstract}

\section{Kata kunci : roti tawar, tepung ubi jalar, tepung tempe, kualitas kimiawi}

\section{PENDAHULUAN}

$\begin{array}{rcr}\text { Roti } & \text { salah satu makanan } \\ \text { alternative } & \text { yang sudah menjadi } \\ \text { kebutuhan } & \text { umum dimasyarakat }\end{array}$

Indonesia, namun harga di tingkat

konsumen masih relative tinggi. Hal

ini disebabkan pembuatan roti

sebagian besar masih memerlukan

tepung terigu sebagai bahan dasarnya

Salah satu upaya mengurangi biaya

produksinya adalah dengan mencari

bahan lain yang dapat mengurangi proporsi tepung terigu namun sekaligus tidak mengurangi kandungan proteinnya yang tinggi.

Salah satu usaha adalah dengan memanfaatkan tepung ubi jalar yang nilai ekonomisnya lebih rendah, kandungan karbohidratnya cukup tinggi namun kendalanya adalah kandungan proteinnya yang rendah Untuk menanggulangi kekurangan protein tersebut maka disubtitusi dengan tepung tempe, 
sehingga produk yang dihasilkan mempunyai nilai gizi yang tetap baik.

Tepung ubi jalar mempunyai potensi menggantikan tepung gandum karena kandungan pati yang tinggi, selain juga mengandung lebih banyak vitamin dan mineral. Harga ubi jalar yang murah diharapkan akan dapat mnengurangi ketergantungan kita pada tepung gandum yang berbahan baku impor, sehingga dengan demikian dapat pula meningkatkan nilai ekonomis dari ubi jalar.

Tempe merupakan makanan hasil fermentasi kedelai. Keunikan atau kekhasan tempe telah menarik minat peneliti dalam negeri maupun manca negara. Penelitian-penelitian mengenai tempe mengungkapkan tempe sebagai makanan yang mudah dicerna, bergizi tinggi dan zat-zat gizinya mudah diserab oleh tubuh. Selain itu tempe mengandung zat-zat yang bersifat antiinfeksi, antioksidan dan hipolipidemik.

Sosanto (1999) menyatakan bahwa makanan formulasi tempe, bahan makanan campuran tempe dan serealia (jagung, beras) atau sagu dapat diolah secara industri menjadi makanan bayi, makanan ibu hamil dan menyusui, makan untuk usia lanjut yang bersiko terhadap penyakit degeneratif seperti penyakit kardivaskuler. Oleh karena itu perlu membuat bahan pangan yang memanfaatkan tempe sebagai bahan dasar sehingga dapat menambah keanekaragaman produk. Salah satu produk pangan yang dapat dihasilkan adalah roti tawar.

\section{METODE PENELITIAN}

\section{Karakteris tik Tepung Komposit}

Bahan baku utama yang digunakan dalam pembuatan roti tawar pada penelitian ini adalah tepung terigu dan tepung ubi jalar. Parameter bahan baku yang dianalisa meliputi kadar air, kadar protein, kadar lemak, kadar abu dan serat kasar Penelitian dilakukan dengan metode Percobaan experimental. Penelitian terdiri dari dua tahap Tahap pertama untuk mendapatkan komposit tepung terigu dan tepung ubi jalar yang paling baik (mendekati reologi tepung terigu) dan selanjutnya digunakan pada tahap kedua. Perlakuan pada tahap pertama adalah penambahan tepung terigu (X1) dan tepung ubi jalar (X2) sebagai berikut:

$\mathrm{A} 0=100 \%$ tepung gandum (kontrol)

$$
\mathrm{A} 1=70 \%(\mathrm{X} 1)+30 \%(\mathrm{X} 2)
$$




$$
\begin{aligned}
& \mathrm{A} 2=60 \%(\mathrm{X} 1)+40 \%(\mathrm{X} 2) \\
& \mathrm{A} 3=50 \%(\mathrm{X} 1)+50 \%(\mathrm{X} 2) \\
& \mathrm{A} 4=40 \%(\mathrm{X} 1)+60 \%(\mathrm{X} 2)
\end{aligned}
$$

Hasil yang terbaik merupakan Y dan selanjutnya digunakan dalam tahap 2 .

Tahap kedua ditujukan untuk mendapatkan formulasi tepung terigu, tepung ubi jalar dan tempe yang paling baik (kualitas kimia ). Adapun perlakuan yang diberikan adalah penggunaan tepung komposit $\mathrm{Y}$ ditambah dengan tempe dengan rincian sebagai berikut:

$\mathrm{B} 0=100 \%$ tepung gandum (kontrol)

$$
\begin{aligned}
& \mathrm{B} 1=\mathrm{Y}+0 \% \text { tempe } \\
& \mathrm{B} 2=\mathrm{Y}+5 \% \text { tempe } \\
& \mathrm{B} 3=\mathrm{Y}+7,5 \% \text { tempe } \\
& \mathrm{B} 4=\mathrm{Y}+10 \% \text { tempe }
\end{aligned}
$$

Perlakuan tersebut masing-masing diulang 5 kali dengan menggunakan Rancangan Acak Kelompok.

Perlakuan yang diberikan untuk mempersiapkan tempe dalam pembuatan roti adalah sebagai berikut:

- Tempe dipotong-potong dadu, kemudian dikukus 5 menit (untuk blanching)

- Tempe kemudian diblender dengan menggunakan air panas selama 3 menit. Hal ini ditukan untuk mengurangi rasa langu dengan menonaktifkan enzim lipoksigenase.

- Bubur tempe dipres untuk menghilangkan air dan siap ditambahkan pada adonan.

\section{Parameter pengamatan}

Bahan baku (raw material) yang terdiri tepung terigu, tepung ubi jalar dan tempe dianalisa proksimat yang meliputi analisa kadar air, kadar protein (metode Kjeldahl), lemak (metode Soxhlet), serat kasar dan abu (Sudarmadji, 1984).. Pada tahap ketiga roti yang dihasilkan dianalisis kadar air, protein, lemak, serat pangan total, Data hasil penelitian dianalisa menggunakan sidik ragam. Apabila hasil menunjukkan pengaruh nyata maka dilanjutkan dengan Uji Jarak Berganda Duncan (Yitnosumarto, 1993).

\section{HASIL DAN PEMBAHASAN \\ Penelitian tahap I}

Pada penelitian Tahap I menentukan proporsi yang tepat untuk tepung komposit yang akan terpilih pada penelitian Tahap II. berdasarkan pemilihan volume adonan roti yang terbaik.

\section{Karakteristik Tepung Komposit \\ Bahan baku utama yang digunakan dalam pembuatan roti}


tawar pada penelitian ini adalah tepung terigu dan tepung ubi jalar. Parameter bahan baku yang dianalisa meliputi kadar air, kadar protein, kadar lemak, kadar abu dan serat kasar (Tabel 1.)

Tabel 1. Hasil analisa Tepung Terigu, Tepung Ubi Jalar dan Tepung Tempe.

\begin{tabular}{|lccc|}
\hline Parameter & Tepung Terigu & Tepung Ubi Jalar & Tepung Tempe \\
\hline Air $(\%)$ & 13,39 & 6,72 & 63,43 \\
Protein $(\%)$ & 12,54 & 2,73 & 18,93 \\
Lemak $(\%)$ & 1,34 & 0,75 & 2,85 \\
Serat Kasar $(\%)$ & 0,52 & 3,64 & 4,92 \\
Abu (\%) & 0,43 & 3,01 & 0,43 \\
& & & \\
\hline
\end{tabular}

Dari Tabel diatas dapat diketahui bahwa tepung tempe mengandung kadar Air, protein, lemak dan serat kasar tertinggi.

\section{Karakteristik Roti Tawar Ubi Jalar Penelitian Tahap II}

Pada penelitian tahap ini, tepung tempe disubtitusikan secara proporsional dengan prosentase masing-masing $5 \%, 7,5 \%$ dan $10 \%$. Masing-masing roti hasil perlakuan dianalisa parameter meliputi volume adonan dan volume roti, sedang terhadap roti dianalisa kadar air, kadar protein, kadar lemak, kadar serat kasar, kadar abu, tekstur dan foto mikroskopis serta uji organoleptik.

\section{Kadar Air Roti}

Penambahan berbagai proporsi tepung tempe menyebabkan kadar air roti berbeda sangat nyata . Terlihat kecenderungan dengan penambahan proporsi tepung tempe menyebabkan kadar air roti meningkat (Tabel 2). Kadar air terendah didapat pada roti dengan penambahan tepung tempe $5 \%$ dengan rerata $30,976 \%$ sedang tertinggi pada roti dari tepung komposit yaitu sebesar 35,952\%. 
Tabel 2. Rerata Kadar Air Roti Akibat Penambahan Berbagai Proporsi Tepung Tempe

\begin{tabular}{|lcccccc|}
\hline Perlakuan & U1 & U2 & U3 & U4 & U5 & Rata-Rata \\
\hline Kontrol & 33,08 & 32,97 & 32,88 & 33,1 & 32,9 & 32,986 a \\
Komposit & 35,91 & 36,03 & 36,07 & 35,87 & 35,99 & 35,952 a \\
Y1 & 31,09 & 31,09 & 30,89 & 30,85 & 30,96 & 30,976 a \\
Y2 & 33,58 & 33,4 & 33,27 & 32,91 & 33,56 & 33,344 a \\
Y3 & 35,82 & 35,65 & 35,78 & 35,92 & 35,51 & 35,736 a \\
& & & & & & \\
\hline
\end{tabular}

Keterangan : Angka-angka yang diikuti huruf yang sama tidak berbeda sangat nyata pada taraf $\mathrm{p} \leq 0,01$ menurut uji Duncan.

Kecenderungan meningkatnya

kadar air pada roti dengan penambahan tepung tempe $10 \%$ disebabkan kadar air tepung tempe masih tinggi yaitu 63,43\% sehingga makin besar proporsi tepung tempe maka meningkat pula kadar air roti.

\section{Kadar Lemak}

Penambahan berbagai proporsi tepung tempe menyebabkan kadar lemak roti berbeda sangat nyata . Terlihat kecenderungan dengan penambahan proporsi tepung tempe menyebabkan kadar lemak roti meningkat (Tabel 3)

Tabel 3. Rerata Kadar Lemak Roti Akibat Penambahan Berbagai Proporsi Tepung

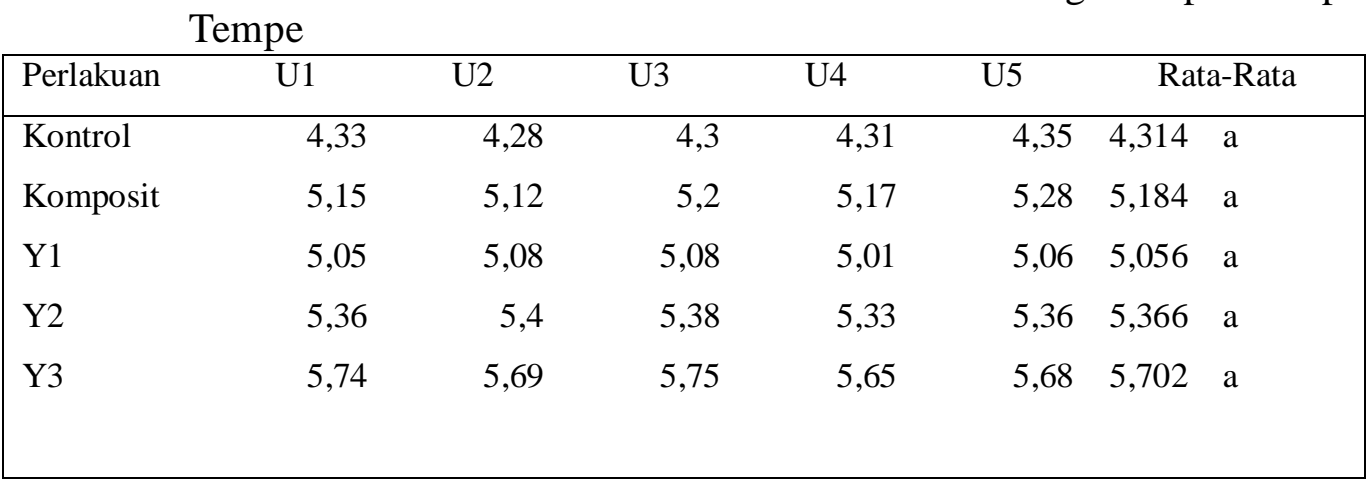

Keterangan : Angka-angka yang diikuti huruf yang sama tidak berbeda sangat nyata pada taraf $\mathrm{p} \leq 0,01$ menurut uji Duncan. 


\section{Kadar Protein}

Penambahan berbagai proporsi tepung tempe menyebabkan kadar Protein roti berbeda sangat nyata. Terlihat kecenderungan dengan penambahan proporsi tepung tempe menyebabkan kadar protein roti meningkat (Tabel 4), namun terlihat pula bahwa dengan pengurangan tepung terigu dan diganti dengan tepung ubi, kadar protein menurun dengan sangat nyata.

Peningkatan protein sampai penambahan tepung tempe $10 \%$ terlihat masih lebih rendah dari roti kontrol. Kadar protein terendah

Tabel 4. Rerata Kadar Protein Roti Akibat Penambahan Berbagai Proporsi

\begin{tabular}{|lcccccc|}
\multicolumn{7}{l}{ Tepung Tempe } \\
\hline Perlakuan & U1 & U2 & U3 & U4 & U5 & Rata-Rata \\
\hline Kontrol & 9,28 & 9,29 & 9,3 & 9,25 & 9,32 & 9,288 a \\
Komposit & 6,6 & 6,65 & 6,71 & 6,55 & 6,58 & 6,618 a \\
Y1 & 7,64 & 7,6 & 7,71 & 7,59 & 7,55 & 7,618 a \\
Y2 & 7,65 & 7,65 & 7,8 & 7,6 & 7,62 & 7,664 a \\
Y3 & 8,18 & 8,2 & 8,15 & 8,1 & 8,25 & 8,176 a \\
& & & & & & \\
\hline
\end{tabular}

Keterangan : Angka-angka yang diikuti huruf yang sama tidak berbeda sangat nyata pada taraf $p \leq 0,01$ menurut uji Duncan.

\section{Serat Kasar}

\footnotetext{
Penambahan berbagai proporsi tepung tempe menyebabkan kandungan serat kasar roti berbeda sangat nyata. Terlihat kecenderungan dengan penambahan proporsi tepung
}

didapat pada roti dari tepung komposit dengan rerata $6,618 \%$ sedang tertinggi pada roti kontrol yaitu sebesar $9,288 \%$.

kadar protein pada roti dengan penambahan tepung tempe dalam tepung komposit diduga disebabkan jenis protein yang ada dalam tempe berbeda dengan protein tepung terigu sehingga dalam proses pemanasan terdegradasi dan kehilangan fungsi sebagaiprotein. tempe tidak menyebabkan kandungan serat kasar roti meningkat (Tabel 5), walaupun kandungan serat kasar tepung tempe lebih tinggi dari tepung terigu maupun tepung komposit. 
Tabel 5. Rerata Serat Kasar Roti Akibat Penambahan Berbagai Proporsi Tepung Tempe

\begin{tabular}{|lcccccc|}
\hline Perlakuan & U1 & U2 & U3 & U4 & U5 & Rata-Rata \\
\hline Kontrol & 0,76 & 0,74 & 0,79 & 0,81 & 0,72 & 0,764 bc \\
Komposit & 1,28 & 1,28 & 1,31 & $\mathbf{1 , 3 3}$ & 1,27 & $1,294 \mathrm{a}$ \\
Y1 & 1,14 & 1,14 & 1,15 & 1,2 & 1,18 & $1,162 \mathrm{a}$ \\
Y2 & 1,52 & 1,49 & 1,55 & 1,47 & 1,44 & $1,161 \mathrm{a}$ \\
Y3 & 0,92 & 1,01 & 1,05 & $\mathbf{0 , 9 8}$ & 0,96 & 0,984 ab \\
& & & & & & \\
\hline
\end{tabular}

Keterangan : Angka-angka yang diikuti huruf yang sama tidak berbeda sangat nyata pada taraf $\mathrm{p} \leq 0,01$ menurut uji Duncan.

Kandungan serat kasar roti berbeda sangat nyata . Terlihat terendah terdapat pada roti kontrol kecenderungan dengan penambahan dengan rerata $0,764 \%$ sedang proporsi tepung tempe menyebabkan tertinggi pada roti tepung komposit kandungan serat kasar roti meningkat yaitu sebesar $1,294 \%$.

(Tabel 6),

\section{Kadar Abu}

Penambahan berbagai proporsi

tepung tempe menyebabkan kadar abu

Tabel 6. Rerata Kadar Abu Roti Akibat Penambahan Berbagai Proporsi Tepung Tempe

\begin{tabular}{|lcccccc|}
\hline Perlakuan & U1 & U2 & U3 & U4 & U5 & Rata-Rata \\
\hline Kontrol & 1,31 & 1,35 & 1,29 & 1,3 & 1,33 & 1,316 c \\
Komposit & 1,74 & 1,74 & 1,78 & $\mathbf{1 , 6 9}$ & 1,75 & $1,740 \mathrm{c}$ \\
Y1 & 2,56 & 2,57 & 2,48 & 2,6 & 2,51 & 2,544 a \\
Y2 & 3,07 & 3,02 & 2,92 & 2,89 & 2,98 & $2,350 \mathrm{ab}$ \\
Y3 & 2,63 & 2,65 & 2,71 & $\mathbf{2 , 7 5}$ & 2,77 & $2,702 \mathrm{a}$ \\
& & & & & & \\
\hline
\end{tabular}

Keterangan : Angka-angka yang diikuti huruf yang sama tidak berbeda sangat nyata pada taraf $p \leq 0,01$ menurut uji Duncan.

Kadar abu terendah terdapat pada roti kontrol dengan rerata 1.316 $\%$ sedang tertinggi pada roti dengan penambahan tepung tempe $10 \%$ yaitu $1,702 \%$. 


\section{KESIMPULAN DAN SARAN}

\section{Kesimpulan}

1. Tepung komposit yang terbaik adalah tepung terigu $80 \%$ dan tepung ubi $20 \%$ yang memberikan dengan kadar lemak $1,07 \%$, kadar protein 10,88\%, kadar air 10,995\%, kandungan serat kasar $0,03 \%$ dan kadar abu $0,92 \%$.

2. Penambahan tepung tempe secara proporsional yang terbaik adalah 5\%, yang memberikan kadar lemak $5,056 \%$, kadar protein $7,618 \%$, kadar air 30,976\%, kandungan serat kasar $1,162 \%$ dan kadar abu 2,544\%,

\section{DAFTAR PUSTAKA}

Alais, C and Linden, G. (1991). Food Biochemistry. Ellis Horwad. New York.

Czuchajouska, Z. Paszczynska, B. Kawka, A and Pomeranz, Y. (1995). Wheat Flour Protein Concentrate Characterization by Biochemical, Physicochemical and Baking Test. J. Food. Sci., 60 (1), 169175.

De Garmo, E.P. Sullivan, W.G and Canada, C.R. (1984).
Engeneering Economy. Ed $7^{\text {th. }}$ Mac. Millan Pulb.C. New York.

Eskin, N.A.M. (1990). Biochemistry of Food. Academic Press Inc. New York.

Fujio, y. (1988). Some Characteristics of Thermo-Processed Wheat Glutenin. Food Sci. and Tech in Industrial Development. P. 229-233. Proceedings of The Food Conference. Bangkok.

Mani, K. Tragrardh, G. Elliasson. A.C. and Lindahl, L. 1992. Water Content, Water Soluble Fraction and Mixing Affect Fundamental Rheological Properties of Wheat Flour Dough. J. Food. Sci. 59(5) 1086-1090.

Pomeranz, Y. (1985). Functional properties of Food Componenta. Academic Precc Inc. New York.

Siffring, K and Bruisma, B.L. (1993). Effect of Proof Temperature on The Quality of Pan Bread. Cereal Chem., 70(3), 351-353

Steel, R.G.D and Torri, J.H. (1991). Prinsip dan Prosedur Statistika Suatu Pendekatan Biometrik. Gramedia Pustaka Utama. Jakarta.

Susanto, T. (1999). Makanan untuk Kesehatan. PT.Bina Ilmu. Surabaya. Yitnosumarto, S. (1991). Percobaan. Rancangan, Analisis dan Interprestasinya. PT. Gramedia. Jakarta. 